\title{
423. 膝関節におけるDESS法の基礎的検討 DESS : a novel MR imaging of Knee-Joint
}

\author{
東京慈恵会医科大学附属病院 放射線科 \\ ○松尾浩一桜井智生. \\ (Kouichi Matsuo) (Tomoo Sakurai) \\ 京橋病院放射線科片野修一 \\ (S ywi chi Katano) \\ シーメンス旭メディテック 水内宣夫 \\ 上野雅之 \\ 矢本俊一 \\ 中村宣男 \\ (Masay uki Ueno) (Syuni chi Yamoto) (Norio Nakamura) \\ 星総合病院放射線科 白石嘉博 \\ (Yos hihi ro Shiroi shi) \\ (Nobuo Mi zuachi)
}

\section{【始めに】 DESS : Double Echo Steady State}

DESS法は，1回の稆り返し時間の間に2 種類のSSFP(Steady Stat Free Precession)状態の信号を 取り込みます。これら 2 種類の信号は第 1 エコー (TE:9 mSec)のFISP信号と第 2 エコー(TE: $47 \mathrm{mSec})$ のPSIF信号で，それぞれ違ったコントラストを示します。今回我々は，㮦関節に拈ける3D-DESS 法の検討をしたので報告いたします。

【目的】㮏関節での3D-DESSの有用性 1) 最適撮像パラメーター 2) 信号特性 3) 検查効率 【方法】前十字勒帯を描出する為, 㮏を 15 度回外位とした矢状断像において，

1) 3D-DESSのFA:(20,30,40,60,80 degrees), TR:(28,56 mSec), ST:(1.0,2.5,5.0 m m) 変化

2 ) 3D-FISP,3D-PSIFと3D·DESSの各画像を, 健常ボランティアと臨休例について比較

【使用装置】Siemens杜製静磁場強度 $1.0 \mathrm{~T}$ esla Magnetom Impact 㑯斜磁場強度 $15 \mathrm{mTes} \mathrm{a} / \mathrm{m}$ 【結果】1）Flip angle変化結果(Figure1)液体はF A が大きくなると，信号強度が特に上昇する が, 他は, 余り変化が無いか, 信号低下傾向。関節軟骨と半月板, 骨皮質の比では, F A $40^{\circ}$ 付 近をピークのコントラストが認められる。

画像比較では，F A 40 付近が明暸に識別でき最も良好なコントラストが得られた。

2) S T, T R 変化結果(Figure2)スライス厚が厚くなると, 信号低下の㑯向がある。T R を変化 させてもコントラストにあまり大きな影輻を与えていない。

画像比較では，スライス厚が厚くなると，画像が量け各組織の分解能が低下する。

․ 1）2）よりスライス厚は，滕関節全体を網羅できるs lab厚が $8 \mathrm{~cm}$ とな $2.5 \mathrm{~mm} ， \mathrm{~T} R$ は撮像時 間考虑し，最短の $28 \mathrm{msec}$ 選択した。臨床画像は，2NEXとしてS/Nを向上させる。

3 ) 3D-FISP,PSIF,DESS画像(Figure3) DESS画像は, 半月板, 関節軟骨, 靯帯はFISP法, 関節 液の貯留はPSIF法と同等に描出され( T2*), 周囲の解剖が明暸であった。

4 ）健常ボランティア滕関節での視覚的評価比㜞では, DESS画像が, 関節液, 䩗帯, 半月板, 関 節軟骨において，同等以上に優れていた。

5 ）缸床例においても，3D-DESSは，ACL・PCL・半月板損傷の描出で3D-FISP,3D-PSIF 画像と 比較して同等以上に優れていた。

【結語】膝関節領域における3D-DESS画像について(1)最適撮像パラメーター：

$\mathrm{TE}(9 / 47) \quad \mathrm{TR}(28) \quad \mathrm{FA}(40) \quad \mathrm{NEX}(2) \quad \mathrm{NS}(32) \quad \mathrm{ST}(2.5) \quad \mathrm{MX}(56 \times 256) \quad \mathrm{Time}(7 \mathrm{~m} 41 \mathrm{~s})$ (2)信号特性は，FISP (T 1)+PSIF(T2*)の信号特性があり，それぞれとの比較では，DESS画像が， 関節液，勒带，半月板，関節軟骨において，同等以上に優れている。

(3) FISP $(2 \mathrm{Nex})+\operatorname{PSIF}(2 \mathrm{Nex})$ 両方を施行すると $13 \mathrm{~m} 44 \mathrm{sec}, \operatorname{DESS}(2 \mathrm{Nex})$ だと $7 \mathrm{~m} 42 \mathrm{sec}$ で斎み, 診断 精度の向上に加之, FISPとPSIFの画像が 1 度に撮像できるため，1回の検査時間内で雨膝の撮像 が可能となりうる等，検査時間の短繀・検査効率の向上が見込まれる。

(4) $3 \mathrm{D}$ 撮像なのでMPR処理が可能，但し精查は，後処理画像の質も考えSTは，1 mmが良好。

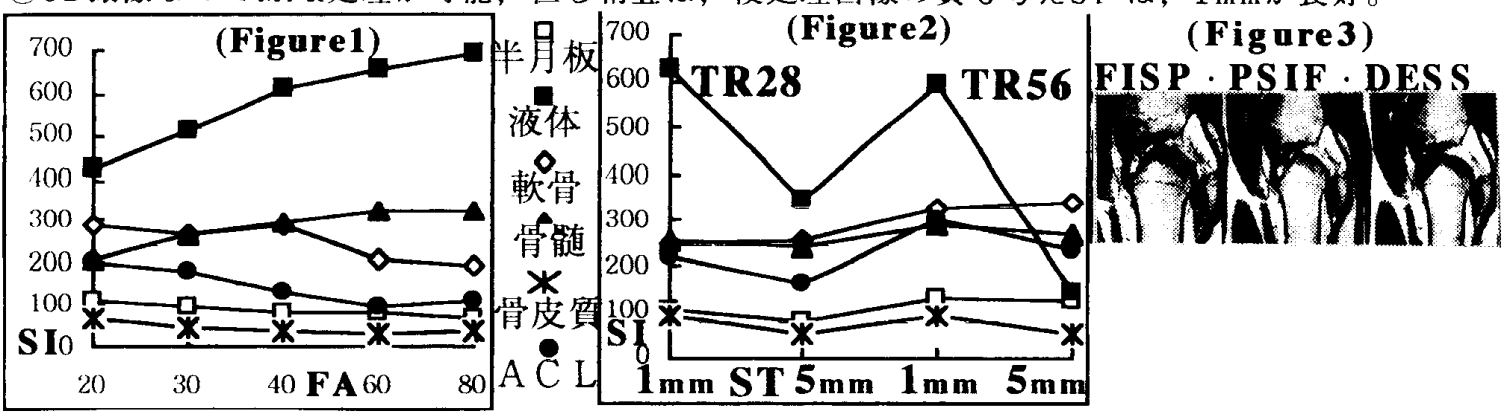

